\title{
Identifikasi Potensi Akuifer Tertekan berdasarkan Data Resistivitas Batuan (Kasus : Kecamatan Sambirejo Kabupaten Sragen)
}

\author{
Darsono, ${ }^{*}$ Budi Legowo, dan Darmanto
}

Laboratorium Geofisika, Jurusan Fisika FMIPA, Universitas Sebelas Maret, Jln. Ir Sutami 36A Kentingan Surakarta 57126

\begin{abstract}
Intisari
Identifikasi lapisan akuifer dalam/tertekan di Kecamatan Sambirejo menggunakan metode geolistrik resistivitas dengan konfigurasi Schlumberger. Pengukuran dilakukan dengan menggunakan Resistivitymeter OYO Mc OHM-EL Model 2119C dengan panjang electrode arus 350 meter. Lokasi pengukuran di Kecamatan Sambirejo sebanyak 5 titik geolistrik yaitu TS1 (DK. Sidoharjo Musuk), TS2 (Ds. Gempol), TS3 (Sambirejo), TS4 (Dagangan, Blimbing) dan TS5 (Sidorejo, Blimbing). Pengolahan data menggunakan Sofware IP2Win versi 3.1.2c. Penelitian ini untuk mengidenfikasi litologi, kedalaman dan ketebalan serta potensi akuifer tertekan di daerah penelitian. Hasilnya menunjukkan bahwa litologi lapisan akuifer yang terdeteksi berupa lapisan pasir lempungan , pasir, pasir kerikilan, pasir kerakalan dan breksi. Kedalaman lapisan akuifer dalam terdeteksi antara 23,95->168,3 m dan ketebalan lapisan antara 39,6-98,4 m. Potensi lapisan akuifer dalam yang mempunyai potensi mempunyai kandungan airtanah besar adalah TS1, TS4 dan TS5.
\end{abstract}

\begin{abstract}
Confined aquifer identification in Sambirejo District using Geoelectric resistivity methods with Schlumbeger array was conducted. The measurement were performed by using a resistvitymeter OYO McOHM-el model $2119 \mathrm{C}$ with a length of current electrode is 350 meters. survey location in Sambirejo Distric with five geolistrik point i.e TS1(Sidoharjo, Musuk), TS2 (Gempol), TS3 (Sambirejo), TS4 (Dagangan, Blimbing) dan TS5 (Sidorejo, Blimbing). The data processing used IP2win software version 3.1.2c. The research is to identify of litology, depth and thick layer with confined aquifer potention at the research area. The result shows that litology of aquifer layers were detected i.e. clayed sands, sands, gravel sands dan breccia. The depth of confined aquifer detect between 23.95 meters to $>168,3$ meters and layers thick between 39,6 meters to 98.4 meters. The Confined aquifer have big groundwater source i.e. TS1, TS4 and TS5.
\end{abstract}

KATA KUNCI: confined aquifer, resistivity, schlumberger, geoelectric, Ip2win http://dx.doi.org/10.12962/j24604682.v13i1.2151

\section{PENDAHULUAN}

Air merupakan kebutuhan yang sangat penting bagi setiap makhluk hidup, dimana setiap makhluk hidup dalam kehidupannya tidak terlepas dari ketergantungannya terhadap air. Peranan airtanah semakin penting karena airtanah menjadi sumber air utama untuk memenuhi kebutuhan pokok hajat hidup orang banyak (common goods), seperti air minum, rumah tangga, industri, irigasi, pertambangan, perkotaan dan lainnya, untuk memenuhi kebutuhan air kebanyakan yang dilakukan dengan memanfaatkan sumber airtanah. Diperkirakan $70 \%$ kebutuhan air bersih penduduk dan $90 \%$ kebutuhan air industri berasal dari air tanah. Air di bumi ini berada di lautan, daratan dan di bawah permukaan tanah yang disebut sebagai airtanah.

Airtanah merupakan komponen dari suatu daur hidrologi (hydrology cycle) yang melibatkan banyak aspek bio-geofisik, bahkan aspek politik dan sosial budaya yang sangat

\footnotetext{
*E-MAIL: onos.dar2014@gmail.com
}

menentukan keterdapatan airtanah di suatu daerah. Sumber airtanah berasal dari air yang ada di permukaan tanah (air hujan, air danau dan sebagainya) kemudian meresap ke dalam tanah/akuifer di daerah imbuhan (recharge area) dan mengalir menuju ke daerah lepasan (discharge area). Aliran airtanah di dalam akuifer dari daerah imbuhan ke daerah lepasan cukup lambat, memerlukan waktu lama bisa puluhan sampai ribuan tahun tergantung dari jarak dan jenis batuan yang dilaluinya. Airtanah adalah air yang bergerak di dalam tanah yang terdapat di dalam ruang antar butir-butir tanah yang kemudian meresap ke dalam tanah dan bergabung membentuk lapisan tanah yang disebut akuifer [1]. Akuifer adalah lapisan batuan yang dapat menyimpan dan meluluskan air [2-4]. Lapisan yang dapat meluluskan air disebut lapisam permeable dan lapisan yang tidak dapat meluluskan air disebut lapisan impermeable.

Permasalahan menipisnya keberadaan sumber airtanah terutama pada musim kemarau, seperti yang terjadi di Kabupaten Sragen, khusunya di Kec. Sambirejo, maka perlu dipikirkan untuk mencari sumber airtanah alternatif. Sumber airtanah berada dalam suatu wadah lapisan yang disebut dengan lapisan akuifer. Lapisan tersebut dapat digo- 


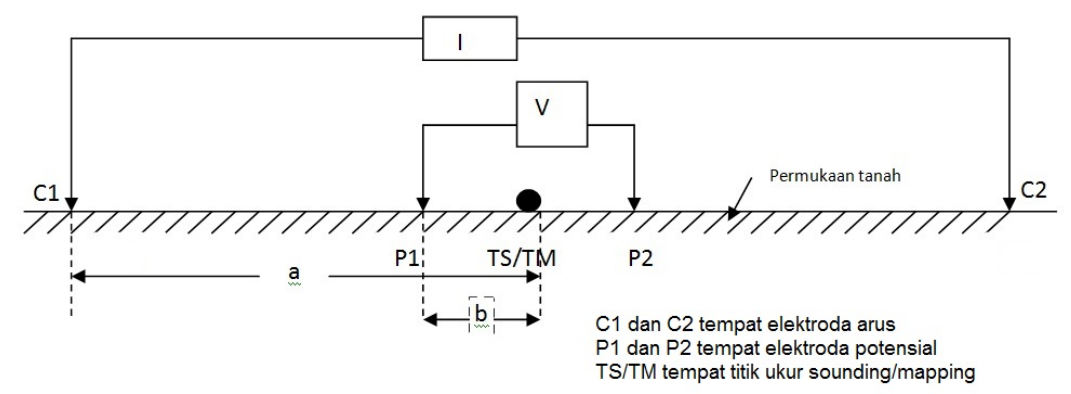

Gambar 1: Skema konfigurasi Schlumberger.

longkan menjadi dua yaitu lapisan akuifer dangkal dan lapisan akuifer dalam/tertekan. Lapisan akuifer dangkal merupakan lapisan akuifer yang sangat banyak dimanfaatkan. Lapisan ini sangat dipengaruhi oleh musim. Sedangkan lapisan akuifer dalam atau lapisan akuifer tertekan merupakan lapisan akuifer yang dibatasi dengan lapisan kedap air/ lapisan impermeable. Lapisan akuifer ini masih jarang dimanfaatkan sebagai sumber airtanah dan keberadaannya berada jauh di bawah permukaan. Keberadaan akan airtanah di suatu tempat berbeda, hal ini tergantung ada tidaknya lapisan batuan yang mengandung airtanah. Kedalaman airtanah di suatu daerah tidak sama dengan daerah lain, tergantung dari ketebalan lapisan di atasnya dan kedudukan akuifer. Sehingga tidak boleh sembarangan bila melakukan pengeboran, apabila melakujkan pengeboran langsung tanpa survey keberadaan akuifer, bisa jadi pengeboran nihil/kosong tanpa mendapatkan sumber air tanah. Untuk mengidentifikasi keberadaan lapisan akuifer dalam dapat dilakukan survey menggunakan salah satu metode geofisika yaitu metode resistivitas.

Penggunaan metode geolistrik resistivitas pernah dilakukan beberapa peneliti sebelumnya, seperti penentuan lapisan akuifer unconfined dengan survei resistivitas [5], pemetaan air tanah dengan metode resistivitas di Taiwan [6], deteksi lapisan akuifer dangkal dengan resistivitas sounding di daerah okitipupa, Nigeria [7], eksplorasi air bawah tanah di kawasan industri Pasuruan [8], pemetaan penyebaran polutan pada air tanah [9], penentuan lapisan akuifer berdasarkan sifat kelistrikan bumi [10], investivigasi kondisi air tanah di Korin Iran [11], gambaran kondisi hidrogeologi dan jenis batuan berdasarkan nilai resistivitasnya [12]. Maksud dan tujuan penyelidikan ini adalah untuk mengetahui kedalaman lapisan akuifer dalam, juga dapat mengetahui potensi aquifer sumber airtanah dalam, dan dapat mengetahui kondisi geologi bawah permukaan tanah.

\section{Metode resistivitas}

Geofisika merupakan cabang ilmu fisika yang mempelajari gejala kebumian atau sifat-sifat fisik pada lapisan bumi yang diukur dari bagian permukaan saja. Untuk mengetahui kondisi bawah permukaan bumi maka diperlukan suatu metode pengukuran, metode ini didasarkan pada pengamatan gejalagejala ganngguan yang terjadi pada keadaan normal. Salah satu metode pengukuran geofisika adalah metode geolistrik resistivitas, dimana metode ini mempelajari sifat resistivi- tas (tahanan jenis) listrik dari lapisan batuan di dalam bumi. Caranya dengan mengalirkan arus ke dalam lapisan bumi melalui 2 elektroda arus, kemudian polarisasi arus tersebut yang menjalar di dalam bumi diukur potensialnya melalui 2 elektroda potensial. Setelah diketahui besar arus dan besar potensial maka dihitung resistivitas semunya dengan rumus [12]:

$$
\rho_{\text {semu }}=K \frac{\Delta V}{I}
$$

dengan $\rho_{\text {semu }}$ adalah resistivitas semu, $\Delta V$ adalah beda potensial, K adalah faktor geometri yang tergantung pada konfigurasi bentangan elektroda, I adalah arus listrik.

Faktor geometri (K) itu tergantung dari konfigurasi/susunan bentangan elektroda yang dipakai dalam pengukuran. Ada beberapa macam aturan / konfigurasi pendugaan lapisan bawah permukaan tanah dengan geolistrik ini, antara lain Wenner, Schlumberger, dipole-dipole. Prosedur pengukuran untuk masing-masing konfigurasi bergantung pada variasi resistivitas terhadap kedalaman yaitu pada arah vertikal (sounding) atau arah horizontal (mapping) [13]. Pada penelitian ini konfigurasi yang digunakan adalah konfigurasi Schlumberger, susunan elektrodanya seperti Gambar 1.

Faktor geometri susunan ini adalah

$$
\begin{aligned}
K S C & =\frac{2 \pi}{\left(\frac{1}{C_{1} P_{1}}-\frac{1}{C_{2} P_{1}}\right)-\left(\frac{1}{C_{1} P_{2}}-\frac{1}{C_{2} P_{2}}\right)} \\
& =\frac{2 \pi}{\left(\frac{1}{a-b}-\frac{1}{a+b}\right)-\left(\frac{1}{a+b}-\frac{1}{a-b}\right)} \\
& =\pi\left(\frac{a^{2}-b^{2}}{2 b}\right)
\end{aligned}
$$

\section{Geologi regional Sragen}

Secara regional kondisi geologi Sragen seperti Gambar 2 terdiri dari 6 formasi batuan yaitu formasi Kalibeng, formasi Kabuh, formasi Notopuro, endapan gunung api muda dan endapan aluvium. Formasi Kalibeng penyebaran sangat luas, formasi ini tersusun oleh napal, berwana abu-abu tua, serta setempat-setempat bersisipan dengan batu pasir berbutir, Pelapukan batuan berupa lempung, berwarna coklat kehitamanan. Formasi Pucangan ditemukan di Sangiran dan Gemolong tersusun dari batu lempung berwarna hitam sering 


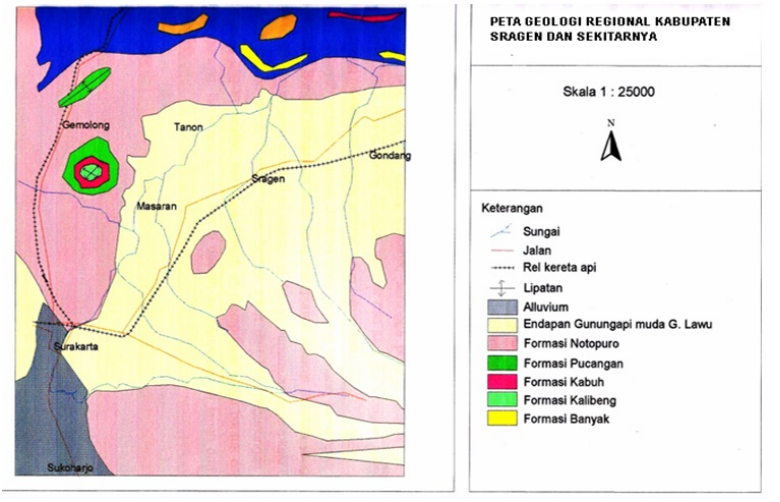

Gambar 2: Peta geologi Sragen.

bersisipan dengan batu pasir. Formasi Kabuh ditemukan di Sangiran, Gemolong dan Sumber Lawang, batuan ini tersusun oleh batu pasir, berwarna abu-abu terang, berbutir sedang sampai kasar, keras, berstruktur silangsiur. Pelapukan batuan berupa lanau lempungan, berwarna coklat kemerahan. Formasi Notopuro tersusun oleh tuf breksi, tuf dan batupasir tufaan. Penyebaran di bagian Barat dan Selatan. Endapan gunung api muda terdapat didaerah penelitian berasal dari kegiatan gunung Lawu. Endapan gunung api muda in terdiri atas lempung, lempung pasiran, pasir lempungan, pasir kerikilan dan breksi volkanik, kedudukan dengna formasi Notopura tidak selaras. Endapan aluvium di temukan di bagian Selatan dan Utara sepanjang sungai Bengawan Solo, tersusun dari batuan lempung dan lempung pasiran dengan sedikit tufaan, pasir dan kerikil. Umumnya lempung dan lanau, berwarna kehitaman, bersifat lunak [14]. Daerah penelitian termasuk dalam formasi endapan gunung api muda Lawu.

\section{METODE}

Penelitian dilakukan di Kecamatan Sambirejo, dilakukan di Desa Musuk (TS1), Desa Gempol (TS2), Desa Sambirejo (TS3), desa Blimbing (TS 4) dan Desa Sidorejo (TS5). Untuk lokasi titik pengukuran geolistrik seperti Gambar 3. Dalam penelitian ini alat yang dgunakan sebagai berikut: resistivitimeter OYO Model 2119C McOHM-EL, 4 buah elektroda, sebagai terminal untuk mentransmisikan arus listrik dan mengukur potensial yang timbul, 4 buah kabel gulungan, masingmasing dengan panjang 400 meter, sebagai penghubung instrumen resistivitimeter dengan elektroda-elektroda, power supply (accu $12 \mathrm{~V}$ ), sebagai sumber tegangan bagi instrumen resistivitimeter OYO, meteran, untuk pengukuran jarak antar titik ukur dan lebar spasi elektroda-elektroda.

Tahapan pelaksanaan penelitian adalah tahap persiapan yaitu tahap ini menyiapkan keperluan pengukuran di lokasi penelitian, seperti menyiapkan alat resistivitymeter dan kelengkapannya, survai awal dilapangan untuk menentukan daerah yangakan diteliti dan juga sekaligus menentukan titik pengukuran. Tahap pengambilan data, yaitu pada tahap ini konfigurasi yang digunakan Schlumberger dengan $\mathrm{AB} / 2 \mathrm{mu}-$ lai $1,5 \mathrm{~m}$ sampai $350 \mathrm{~m}$. dengan mengetahui arus yang di-

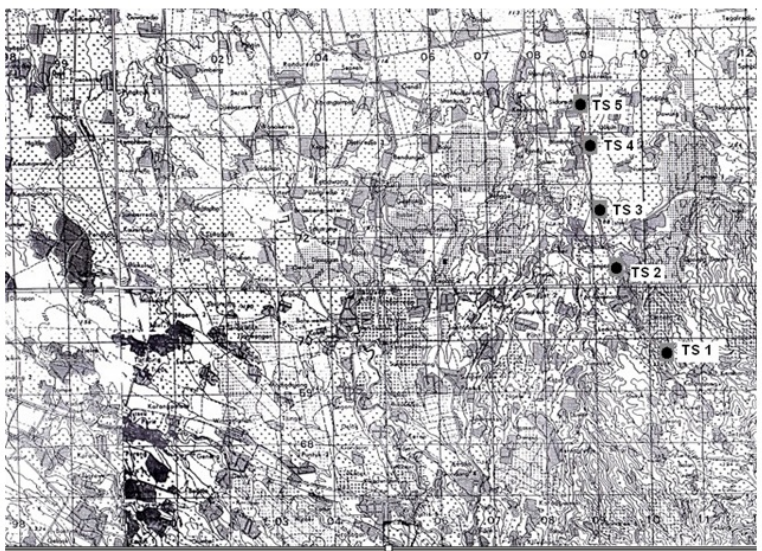

Gambar 3: Lokasi titik pengukuran geolistrik.

TABEL I: Hasil pendugaan pada titik pengukuran TS1 (Sidoharjo Musuk).

\begin{tabular}{cccll}
\hline \hline $\begin{array}{c}\text { Kedalaman } \\
(\mathrm{m})\end{array}$ & $\begin{array}{c}\text { Keteba- } \\
\text { lan }(\mathrm{m})\end{array}$ & $\begin{array}{c}\text { Tahanan } \\
\text { Jenis }(\Omega \mathrm{m})\end{array}$ & Litologi & Keterangan \\
\hline & & & & \\
$0-0,55$ & 0,55 & 115 & Lap. Top Soil & Lapisan penutup \\
$0,55-0,77$ & 0,22 & 216 & Breksi & Akuifer \\
$0,77-1,53$ & 0,77 & 4,64 & Lempung & Non Akuifer \\
$1,53-2,29$ & 0,76 & 1295 & Lava Andesit & Non Akuifer \\
$2,29-3,7$ & 1,4 & 1101 & Lava andesit & Non Akuifer \\
$3,7-4,75$ & 1,06 & 95 & Pasir kerikilan & Akuifer \\
$4,75-5,96$ & 1,21 & 47,7 & Pasir & Akuifer \\
$5,96-8,01$ & 2,05 & 9,38 & Lempung pasiran Non Akuifer \\
$8,01-10,2$ & 2,23 & 11,1 & Lempung pasiran Non Akuifer \\
$10,2-13,2$ & 2,91 & 31,1 & Pasir & Akuifer \\
$13,2-41,7$ & 28,5 & 189 & Pasir kerakalan & Akuifer \\
$41,7-55,5$ & 13,9 & 0,46 & lempung & Non Akuifer \\
$55,5-73,1$ & 17,5 & 64,6 & Pasir & Akuifer \\
$73,1-114$ & 40,7 & 23,1 & Pasir lempungan & Akuifer \\
$114-154$ & 40,2 & 42,2 & Pasir & Akuifer \\
$>154$ & & 146 & Pasir kerikilan & Akuifer \\
\hline \hline
\end{tabular}

injeksikan dan tegangan yang diukur, selanjutnya di hitung niali resistivitas semunya. Tahap Pengolahan data, pengolahan data resistivitas dilakukan dengan menggunakan software IPi2win. Hasil yang diperoleh adalah kedalaman lapisan, ketebalan lapisan dan nilai resistivitas sesungguhnya. Tahap interpretasi, mengubah hasil pengolahan data menjadi bentuk geologi, dengan melihat geologi daerah penelitian.

\section{HASIL DAN PEMBAHASAN}

Hasil pendugaan geolistrik berdasarkan hasil pengolahan data geolistrik di setiap titik pengukuran dan dengan mempertimbangkan kondisi geologi daerah penelitian, dimana termasuk dalam zona endapan Lawu yang tersusun terdiri dari batuan pasir gunungapi, batuan lempung, dan breksi dan hidrogeologi serta memperhatikan referensi kisaran nilai tahanan jenis batuan, maka selanjutnya dikelompokkan jenis batuan 
TABEL II: Hasil pendugaan pada titik pengukuran TS2 (Gempol).

\begin{tabular}{cccll}
\hline \hline $\begin{array}{c}\text { Kedalaman } \\
(\mathrm{m})\end{array}$ & $\begin{array}{c}\text { Keteba- } \\
\text { lan }(\mathrm{m})\end{array}$ & $\begin{array}{c}\text { Tahanan } \\
\text { Jenis }(\Omega \mathrm{m})\end{array}$ & Litologi & Keterangan \\
\hline & & & & \\
$0-1,6$ & 1,6 & 30,4 & Lap. Top Soil & Lapisan penutup \\
$1,6-2,46$ & 0,85 & 119 & Pasir kerikilan & Non Akuifer \\
$2,46-4,51$ & 2,05 & 4,77 & Lempung & Akuifer \\
$4,51-4,95$ & 0,43 & 28,1 & Pasir & Akuifer \\
$4,95-7,16$ & 2,21 & 439 & Breksi & Akuifer \\
$7,16-9,03$ & 1,89 & 334 & Breksi & Akuifer \\
$9,03-13$ & 3,94 & 148 & Pasir kerikilan & Akuifer \\
$13-16,2$ & 3,19 & 0,92 & Lempung/padas & Non Akuifer \\
$16,2-26,5$ & 10,3 & 2,08 & Lempung & Non Akuifer \\
$26,5-30,5$ & 4,16 & 12,7 & Lempung pasiran Non Akuifer \\
$30,5-58,4$ & 27,7 & 51,1 & Pasir & Akuifer \\
$58,4-71,9$ & 13,5 & 19,7 & Pasir lempungan & Akuifer \\
$71,9-81,6$ & 9,67 & 15,5 & Pasir lempungan & Akuifer \\
$81,6-132$ & 50,7 & 0,137 & Lempung & Non Akuifer \\
$>132$ & & 18,4 & Pasir lempungan & Akuifer \\
\hline \hline
\end{tabular}

TABEL III: Hasil pendugaan geolistrik di titik sounding TS3 (Sambirejo).

\begin{tabular}{cccll}
\hline \hline $\begin{array}{c}\text { Kedalaman } \\
(\mathrm{m})\end{array}$ & $\begin{array}{c}\text { Keteba- } \\
\text { lan }(\mathrm{m})\end{array}$ & $\begin{array}{c}\text { Tahanan } \\
\text { Jenis }(\Omega \mathrm{m})\end{array}$ & Litologi & Keterangan \\
\hline & & & & \\
$0-0.75$ & 0,75 & 21,1 & Lap.Top soil & Lapisan penutup \\
$0,75-3,7$ & 2,95 & 15,1 & Pasir lempungan & Akuifer \\
$3,7-34,5$ & 30,8 & 21,4 & Pasir lempungan & Akuifer \\
$34,5-74,1$ & 39,6 & 30,2 & Pasir & Akuifer \\
$74,1-114$ & 39,9 & 11,2 & Lempung pasiran & Akuitar \\
$114-204$ & 89,7 & 2,85 & Lempung & Non Akuifer \\
$>204$ & & 7,86 & Lempung pasiran Non Akuifer \\
\hline \hline
\end{tabular}

berdasarkan nilai tahanan jenis sebenarnya. Hasil yang diperoleh dari 5 titik pengukuran seperti dalam Tabel I hingga Tabel V masing-masing untuk TS1 (lokasi titik di Dk.Sidoharjo Desa Musuk), TS2 (lokasi titik di Gempol), TS3 (lokasi titik di Desa Sambirejo), TS 4 (Lokasi titik di Dagangan Desa Blimbing), dan TS5 (lokasi titik di Desa Sidorejo).

Dari kelima titik pengukuran geolistrik (TS1, TS2, TS3, TS4 dan TS5), litologi yang terdeteksi berupa lapisan lem-

TABEL IV: Hasil pendugaan pada titik pengukuran TS4 (Dk. Dagangan, Blimbing, Kec. Sambirejo).

\begin{tabular}{cccll}
\hline \hline $\begin{array}{c}\text { Kedalaman } \\
(\mathrm{m})\end{array}$ & $\begin{array}{c}\text { Keteba- } \\
\text { lan }(\mathrm{m})\end{array}$ & $\begin{array}{c}\text { Tahanan } \\
\text { Jenis }(\Omega \mathrm{m})\end{array}$ & Litologi & Keterangan \\
\hline & & & & \\
$0-1,11$ & 1,11 & 21,61 & Top soil & $\begin{array}{l}\text { Lapisan penutup } \\
\text { akuitar }\end{array}$ \\
$1,11-2,05$ & 0,94 & 10,40 & Lempung pasiran \\
$2,05-2,34$ & 1,29 & 79,70 & Pasir kerikilan & Akuifer \\
$2,34-32,77$ & 30,43 & 52,58 & Pasir & Akuifer \\
$32,77-58,16$ & 25,39 & 53,25 & Pasir & Akuifer \\
$58,16-97,19$ & 39,03 & 2,77 & Lempung & Akuiklud \\
$97,19-113,3$ & 16,18 & 0,63 & Lempung & Akuiklud \\
$113,37-168,3$ & 54,96 & 36,34 & Pasir & Akuifer \\
$>168,33$ & & 160,23 & Pasir kerakalan & Akuifer \\
\hline \hline
\end{tabular}

TABEL V: Hasil pendugaan pada titik pengukuran TS5(Dk Sidorejo, Blimbing, Kec. Sambirejo).

\begin{tabular}{cccll}
\hline \hline $\begin{array}{c}\text { Kedalaman } \\
(\mathrm{m})\end{array}$ & $\begin{array}{c}\text { Keteba- } \\
\text { lan }(\mathrm{m})\end{array}$ & $\begin{array}{c}\text { Tahanan } \\
\text { Jenis }(\Omega \mathrm{m})\end{array}$ & Litologi & Keterangan \\
\hline & & & & \\
$0-1,07$ & 1,07 & 21,25 & Top soil & Lapisan penutup \\
$1,07-1,59$ & 0,52 & 4,82 & Lempung & Akuiklud \\
$1.59-7,99$ & 6,4 & 36,61 & Pasir & Akuifer \\
$7.99-12,85$ & 4,86 & 75,86 & Pasir kerikilan & Akuifer \\
$12.85-23,95$ & 11,1 & 5,49 & Lempung & Akuiklud \\
$23.95-58,75$ & 34,80 & 42,39 & Pasir & Akuifer \\
$58.75-72,54$ & 13,79 & 1,09 & Lempung & Akuiklud \\
$72.54-101,63$ & 29,9 & 1,59 & Lempung & Akuiklud \\
$101.63-148,29$ & 46,66 & 33,42 & Pasir & Akuifer \\
$>148.29$ & 354,91 & Breksi & Akuifer & \\
\hline \hline
\end{tabular}

pung, lapisan lempung pasir, lapisan pasir lempungan, lapisan pasir, lapisan pasir kerikilan, lapisan pasir kerakalan, breksi dan lava. Lapisan batuan yang bukan lapisan akuifer berupa lapisan lemnpung, lempung pasiran dan lava, sedangkan lapisan akuifer berupa lapisan pasir lempungan, pasir, pasir kerikilan, pasir kerakalan dan breksi. Lapisan lempung merupakan lapisan yang kedap air atau tak lulus air sehingga tidak dapat menyimpan air, lapisan ini merupakan lapisan non akuifer (akuiclud). lapisan lempung pasiran merupakan lapisan akuitar yang dapat menyimpan air tanah, tetapi lapisan ini hanya dapat mengalirkan air tanah dengan jumlah terbatas, serta mempunyai kelulusan air yang kecil sehingga potensi menyimpan kandungan air relatif kecil. Lapisan pasir lempungan mempunyai sifat dapat kelulusan air dengan kategori sedang, sehingga potensi menyimpan air sedang. Lapisan pasir lempungan disebut lapisan akuifer sedang. lapisan pasir, pasir kerikilan pasir kerakalan dan breksi merupakan lapisan akuifer, yang mempunyai kelulusan air yang sangat besar sehingga lapisan ini mempunyai potensi menyimpan kandungan air yang sangat besar.

Pada TS1, lapisan akuifer dangkal terdeteksi sampai kedalaman 41,7 m dengan litologi berupa lapisan pasir, pasir kerikilan dan pasir kerakalan. Sedangkan lapisan akuifer dalam/tertekan terdeteksi dari kedalaman 55,45 m sampai kedalaman diatas $154 \mathrm{~m}$ dengan litololgi berurutan pasir, pasir lempungan, pasir, dan pasir kerikilan. Artinya lapisan akuifer dalam pada TS1 sangat berpotensi mempunyai kandungan jumlah airtanah yang besar. Pada titik TS2, lapisan akuifer dangkal terdeteksi sampai kedalaman $13 \mathrm{~m}$, dengan litologi lapisan akuifer berupa pasir,breksi dan pasir kerikilan. Sedangkan lapisan akuifer dalam terdeteksi dari kedalaman 30,5 sampai kedalaman diatas $132 \mathrm{~m}$ dengan litologi pasir dan pasir lempungan. Lapisan akuifer dalam menunjukkan bahwa kandungan airtanah mempunyai jumlah yang sedang. Pada titik TS3, lapisan akuifer yang berupa lapisan pasir lempungan yang terdeteksi pada kedalaman kurang dari 34,5 m sebagai akuifer dangkal sedangkan lapisan akuifer dalam merupakan lapisan yang terdeteksi pada kedalaman antara 34,5 m sampai 74,1 m dengan litologi pasir. Pada titik TS4, lapisan akuifer berupa lapisan pasir kerikilan dan pasir yang terdeteksi pada kedalaman kurang dari 32,77 m merupakan lapisan 
TABEL VI: Litologi, ketebalan lapisan untuk lapisan akuifer Tertekan.

\begin{tabular}{|c|c|c|c|c|}
\hline $\begin{array}{c}\text { Titik } \\
\text { Geolistrik } \\
\end{array}$ & Litologi & $\begin{array}{l}\text { Kedalaman } \\
(\mathrm{m})\end{array}$ & $\begin{array}{l}\text { Ketebalan } \\
(\mathrm{m})\end{array}$ & Potensi \\
\hline TS1 & $\begin{array}{l}\text { Pasir, } \\
\text { pasir lempungan, } \\
\text { pasir kerikilan }\end{array}$ & $55,5->154$ & 98,4 & $\begin{array}{l}\text { Besar } \\
\text { sangat besar }\end{array}$ \\
\hline TS2 & $\begin{array}{l}\text { Pasir dan } \\
\text { pasir lempungan }\end{array}$ & $30,5-81,6$ & 50,8 & Sedang-besar \\
\hline TS3 & pasir & $34,5-74,1$ & 39,6 & Sedang \\
\hline TS4 & $\begin{array}{l}\text { Pasir, } \\
\text { pasir kerakalan }\end{array}$ & $32,77->168,3$ & 80,35 & Besar \\
\hline TS5 & Pasir, breksi & $23,95->148$ & 80,14 & Besar \\
\hline
\end{tabular}

akuifer dangkal. Lapisan akuifer dalam berupa lapisan pasir, dan pasir kerikilan yang terdeteksi pada kedalaman antara 32,77 m sampai 168,33 m. lapisan akuifer dalam diperkirakan mempunyai kandungan airtanah dalam jumlah yang besar, sehingga sangat potensi sebagai sumber airtanah. Pada titik TS5, lapisan akuifer terdeteksi pada kedalaman kurang dari 12,85 m merupakan l;apisan akuifer dangkal dengan litologi pasir dan pasir kerikilan. Sedangkan lapisan akuifer yang terdeteksi pada kedalaman antara 23,5 m sampai $148 \mathrm{~m}$ dengan litologi lapisan berupa lapisan pasir dan breksi meruipakan lapisan akuifer dalam. Lapisan akuifer dalam yang terdeteksi mempunyai kandungan jumlah air yang besar.

Dari kelima titik geolistrik (TS1,TS2,TS3,TS4 dan TS5), lapisan akuifer dalam/tertekan terdeteksi seperti Tabel VI, menunjukkan bahwa potensi lapisan akuifer yang terdeteksi pada TS1, TS4 dan TS5 mempunyai potensi sumber airtanah yang besar dibandingkan dengan titik geolistrik TS2 dan TS3. Dengan demikian apabila akan dilakukan pengeboran sumur dalam untuk mendapatkan debit sumber airtanah yang besar, maka dapat direkomendasikan secara prioritas untuk lokasi pengeboran adalah TS1 dan TS4 atau TS5.

\section{SIMPULAN}

Penelitian ini adalah mengidentifikasi lapisan akuifer dalam dan potensinya berdasarkan survey geolistrik resistivitas, hasilnya dapat disimpulkan:

1. Litologi lapisan akuifer yang terdeteksi berupa lapisan pasir lempungan, pasir, pasir kerikilan, pasir kerakalan dan breksi.

2. Kedalaman lapisan akuifer tertekan terdeteksi antara 23,95->168,3 m dan ketebalan lapisan antara 39,6-98,4 $\mathrm{m}$.

3. Potensi lapisan akuifer dalam/tertekan yang mempunyai potensi mempunyai kandungan airtanah besar adalah TS1, TS4 dan TS5.
[1] A. Herlambang, Kualitas Air Tanah Dangkal Di Kabupaten Bekasi, Thesis, Program Pascasarjana, IPB, Bogor, 1996.

[2] E. Seyhan, Fundamental Of Hidrology, Geografisch Institut der Rijks Universiteit te Utrecht, Utrecht, 1997.

[3] S. Simoen, Sistem Akuifer di Lereng Gunung Api Merapi Bagian Timur dan Tenggara: Studi Kasus di Kompleks mataair Sungsang Boyolali Jawa Tengah, Majalah Geografi Indonesia, 15(1), 141-152 (2001).

[4] S. Purnama, Infiltrasi Di Kecamatan Nguter Kabupaten Sukoharjo Propinsi Jawa Tengah, Majalah Geografi Indonesia, 18(1), 1 -14 (2004).

[5] J.W. Konster, and D.L. Harry, Hydrology Day, 111-120 (2005).

[6] H.C. Yang, et al., TAO (Terresrial, Atmospheric and Oceanic Sciences Journal), 8(3), 313-328 (1997).

[7] G.O. Omosuyi, J.S. Ojo, and M.O. Olorenfemi, The Pasific journal of Science and Technology, 9(2), 562-570 (2008).

[8] M. Noor Ali, Eksplorasi Dan Pengembangan Sumber Daya Mineral Air Bawah Tanah: Studi Kasus Di Kawasan Industri Pa- suruan Jawa Timur, Proceedings Of Joint Convention Jakarta, 2003.

[9] Darsono, Kombinasi Resistivitas Sounding Dan Mapping Untuk Memetakan Penyebaran polutan Sumber Air Tanah, Laporan PDM, UNS, 2006.

[10] W. Cahyo, $d k k$., Jurnal ilmiah Flux. Unlam. Banjar Baru. Kalimantan., 5(1), 23-27 (2008).

[11] G.R. Lashkaripour, Jurnal Of Spatial Hydrology, 3(1), 1-5 (2003).

[12] W.M. Telford, L.P. Geldart, R.E. Sheriff, D.A. Keys, Applied Geophysics (Cambridge University Press, 1998).

[13] L. Hendrajaya, dan I. Arif, Geolistrik Tahanan Jenis (Laboratorium Fisika Bumi Jurusan Fisika FMIPA, ITB, 1990).

[14] Suharyadi, Laporan Akhir Penelitian Geolistrik Di Kecamatan Gemolong Kab. Sragen, Laboratorium Geologi Tata Lingkungan Jurusan Teknik Geologi Fakultas, Universitas Gadjah Mad, Yogyakarta, 2004. 